UDC 332; DOI 10.18551/rjoas.2022-01.22

\title{
INCREASING THE ECONOMIC VALUE OF BEEF CATTLE BUSINESS WASTE IN THE INTEGRATION SYSTEM WITH FOOD CROPS IN GORONTALO REGENCY, INDONESIA
}

\author{
Marwaty Rita Susana*, Ihsan M. Nur, Wisaptiningsih Umi, Suyadi S. \\ Postgraduate Program of Animal Science, University of Brawijaya, Indonesia \\ *E-mail: suyadi@ub.ac.id
}

\begin{abstract}
Gorontalo Regency is part of the Gorontalo Province which is divided into 19 sub-districts that have the potential to develop beef cattle business. This research was conducted in 3 sub-districts and 6 villages in Gorontalo district from April to June 2018 using the survey method. Data were obtained from interviews, focus group discussions and filling out questionnaires from 100 respondents, while secondary data was obtained through documentation from reports from previous agencies and researchers. The data analysis used linear programming analysis. The linear programming model that was compiled to achieve the goal of maximizing the optimization model of farming and beef cattle business consisted of several alternative activities and resource constraints which were analyzed at the farmer level. The results showed that the potential availability of agricultural waste for food crops and cattle waste that owned by the farmers make it possible to implement integrated crop and livestock farming. Based on the allocation of land, labor, capital and feed availability, the ability of livestock to provide compost, the income obtained through the integration of ricecorn-cattle is 20.94 percent higher than without integration. Corn-cattle and rice-cattle are determined by the availability of the market for intermediate products and the level of crop production. Crop production that is low or below 50 percent of normal production results in lower income.
\end{abstract}

\section{KEY WORDS}

Beef cattle, business, food crops integration.

The development of an integrated farming business between beef cattle and food crops called the crop livestock system (CLS) is an alternative that must be developed. Therefore, it is necessary to conduct further studies and research on integrated farming between livestock and plants so that a reference system of beef cattle with food crops for business development will be obtained that support each other.

Technological innovation in the form of integrated agriculture is a sustainable system in which the waste generated will be reused into usable resources. The concept of a zero waste production system is that all waste from livestock and plants is recycled and reused into the production cycle. The importance of implementing the integration of beef cattle business with food crops is caused by several things, including; (1) Beef cattle dung produces methane gas $(\mathrm{CH} 4)$ which if not utilized can be a greenhouse gas effect which is one of the causes of global warming (global warming), on the other hand the methane gas produced can be used as biogas as a cheap energy source that is environmentally friendly as a substitute for conventional fuels which are increasingly expensive and scarce. Furthermore, livestock manure materials, both liquid, slurry, and solid products from gas utilization can be used as organic fertilizer for high-value plants (2) The scarcity of inorganic fertilizers causes prices to soar, while on the other hand the consequences of inorganic fertilizers on human health encourages the importance of using organic fertilizers, and (3) limited forage land for animal feed while the increase in population continues to increase which will impact on the lack of availability of feed which is also a problem that must be overcome.

Gorontalo Regency with an area of $\pm 1,750.83 \mathrm{Km} 2$, consisting of $11,271 \mathrm{Ha}$ of irrigated land, 2,704 $\mathrm{Ha}$ of rained land, with a population of 355,988 people or $34.22 \%$ (BPS. Gorontalo 2015) of the total population in Gorontalo Province. Gorontalo Regency, which has 
19 sub-districts, with farmers scattered in several areas, has carried out agricultural activities in the form of integrating livestock crops with food crops but not yet maximal.

Agricultural waste in general has not been used optimally for cattle, which at harvest time are abundant and only burned. From the data above, it can be seen that food plant waste that can be used as fibrous feed material has the potential but has not been utilized, this is due to the lack of understanding of farmers.

The potential of a very supportive area in Gorontalo Regency where the total population of cattle in 2018 is 89,110 cattle, with a forage area of 151 ha, the number of human resources $(\mathrm{HR})$ is quite adequate, but on the other hand, with the number of cattle that are still far from the need and availability of beef, the Gorontalo Regency government will continue to increase the number of cattle population through livestock development programs.

The development of livestock business on the other hand faces various obstacles, including the unavailability of continuous mass feed, but on the other hand, potential agricultural waste in the form of rice straw and corn waste can be a source of fibrous feed for cattle farming which has not been utilized. With the increasingly limited use of land, the arrangement of the area for livestock business is not optimal, on the other hand the intensification of livestock business activities results in an abundance of livestock manure and tends to disturb the environment. This also provides new prospects in realizing environmentally friendly agricultural development by simple technological innovations that can convert livestock manure into organic fertilizer in an effort to improve the nutrients of agricultural land. The problems mentioned above, namely the tendency to decrease the level of soil fertility due to the limited content of soil organic matter and the development of optimal cattle farming business can be overcome simultaneously.

\section{METHODS AND MATERIALS OF RESEARCH}

The research was carried out in Gorontalo Regency in three sub-districts and six villages, carried out from April to June 2018. The location of the research was determined purposively.

The method of determining the sample to explore the information and knowledge under study was chosen intentionally (purpose sampling). The selection of samples is adjusted to environmental conditions with criteria that can represent and understand the problems studied. Determination of the sample of farmers for the socio-economic survey was carried out by purposive sampling method. The data used in this study are primary data and secondary data. Primary data were obtained from direct observation in the field (observation), interviews, Focus Group Discussion (FGD) and filling out questionnaires. Secondary data is obtained through report documentation from relevant agencies.

The data collected was then analyzed by using a linear program model analysis method which was arranged to achieve the goal of maximizing the optimization model of farming and beef cattle business consisting of several alternative activities and resource constraints which were analyzed at the farmer level using a linear program in this study is as follows:

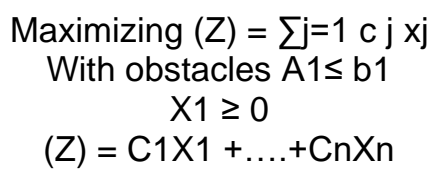

With the following limiting factors:

$$
\begin{aligned}
& a 11 x 1+a 12 x 2+\ldots . . a 1 j x j+\ldots . .+a 1 n X n b 1 \\
& a 21 x 1+a 22 x 2+\ldots \ldots . . a 2 j x j+\ldots .+a 2 n X n b 2 \\
& a j 1 \times 1+a 12 \times 2+\ldots \ldots . . a 1 j \times 2+\ldots .+ \text { ainxnbi } \\
& a m 1 x 1+a m 2 x 2+\ldots \ldots . a m j x 2+\ldots .+\operatorname{ain} X n \\
& \text { Xj } 0 \text { forj: } 1,2,3, \ldots n
\end{aligned}
$$


Where: $Z$ = Objective function i.e. optimized value; $X 1=$ Activity level to $j ; C j=$ Coefficient of objective function for activity $\mathrm{j}$; Aij $=$ The number of resources to which needed to produce each unit of output of activity to $j ; b=$ Number of available resources; $I=1,2,3, \ldots m ; j=1,2$, $3, \ldots \mathrm{n}$.

In this study, the activities used are production activities, product sales activities, consumption activities, capital borrowing activities, activities to hire workers from outside farming food crops, and beef cattle. The basic linear planning matrix used in general consists of three main components:

1. Production line cost factor;

2. Activity column factors, namely:

- Food crop production activities (rice, corn, peanuts);

- Beef cattle production activities;

- Forage production activities for animal feed;

- Sales of food crops (rice, corn and peanuts);

- Beef cattle sales activities;

- The activity of selling livestock manure;

- Capital lending activities;

- Activities of hiring/wage labor.

3. Resource constraint lane factors, namely

- Land;

- Labor;

- Capital;

- Availability of forage fodder.

With conditions or constraints:

$\begin{array}{ll}\text { Land area: } \sum \sum \mathrm{a} i \mathrm{jxj} \leq \mathrm{Ai} & \mathrm{m} n \\ & \mathrm{i}=1 \mathrm{j}=1 \\ & \mathrm{~m} \mathrm{n} \\ & \mathrm{i}=1 \mathrm{j}=1 \\ & \mathrm{~m} \mathrm{n}\end{array}$

Capital: $\Sigma \Sigma c$ ijxj $\quad \leq \mathrm{Ci} \quad \mathrm{i}=1 \mathrm{j}=1$

$\mathrm{m} n$

Availability of Forage: $\Sigma \sum \mathrm{a} \mathrm{ijxj} \quad \leq \mathrm{Ai}$

$\mathrm{i}=1 \mathrm{j}=1$

$x j \leq 0$ for $j=1,2,3, \ldots \ldots . . n$

Where:

Ai: the area of land available for each family (ha) in the i-th planting season;

$\mathrm{Bi}$ : number of available manpower in the first month (HKP/month);

$\mathrm{Cj}$ : the amount of capital available in one season / year;

Dj: the amount of forage available in one year;

a ij: coefficient of input output area of cultivated land;

b ij: labor requirement in the i-th month of the j-plant (HKP/month/ha);

$\mathrm{c}$ ij: cost requirement in month i of the jth plant (Rp);

d ij: need for forage fodder;

$\mathrm{n}$ : the number of plants cultivated;

$\mathrm{m}$ : the number of available and needed resources. 
After the optimal analysis results are obtained, then the sensitivity analysis of each activity and resource use is carried out. The existence of deterministic assumptions in the analysis of linear programming causes the developed capital to be prepared in a state of full certainty, in fact a situation that is really difficult to occur. Sensitivity analysis is carried out to anticipate uncertain conditions due to error factors or changes to model variables. These changes are divided into changes in the objective function coefficient (objective function sensitivity) and changes in resource constraints. Determination of sensitivity analysis was a changes in output prices, production input prices and the resulting production level (BPTP Yogya, 2006; Shinta, 2011). Sensitivity analysis is done by:

- Changes in the selling price of cattle which is decreasing and increasing by $20 \%$ with fixed production costs;

- Changes in the selling price of dry milled rice which is decreasing and increasing by $10 \%$ with fixed production costs;

- Changes in cattle production which is decreasing and increasing by $25 \%$ with fixed production costs;

- Changes in the production of dry milled grain which is down and up by $20 \%$ with fixed production costs;

- Changes in production costs are increased by $10 \%$ and $20 \%$ with the assumption that the selling price and production are fixed.

\section{RESULTS AND DISCUSSION}

Gorontalo Regency with an area of 2,125.47 Km2 with a population of 397.201 people, livelihood is dominated by agriculture and animal husbandry. Farmers generally cultivate the land according to rainfall and also take care of raising livestock together.

Agricultural waste is the by-product of production that can still be used as animal feed, including straw and rice bran. Rice bran is generally sold for IDR 1,500 to IDR 2,000 per kilogram in 70-80 kg sacks, while rice straw is left to pile up on the land. Utilization of agricultural waste is not optimal because it is still considered less useful so that most of it is burned, even though if it is used as feed it will have economic value and can increase farmers' income.

The problem that is often faced by the community in the livestock business is the byproduct in the form of waste where if the amount exceeds the limit and is not controlled. Livestock waste consists of solid waste such as feces, leftover feed, skin, bones, fat and others. Liquid waste includes urine, water used both for drinking and for cleaning cages. Waste in the form of gas consists of ammonia, sulfur, methane, and H2S. These wastes if left unchecked can cause potential environmental pollution that can disturb the community.

The potential for the development of livestock production, including the cattle-plant integration system farming in Indonesia, is very large, supported by the potential of land resources for agricultural development, namely: 100.7 million ha of which the waste can be sufficient for cattle feed biomass throughout the year (1-3 cows/ha). If not utilized, agricultural waste can become a problem and obstacle in agribusiness, because at harvest time it is wasted and becomes a pollutant (Research and Development Center for Agricultural Land Resources, 2009).

Environmentally friendly livestock is a priority for ruminant livestock because it is one of the producers of methane gas $(\mathrm{CH}$,$) which has an impact on the environment. Fermentation$ from 1 unit digester of 12 cows manure can produce liquid fertilizer of around $180 \mathrm{~kg} / \mathrm{sec}$ and biogas energy for gas stoves for 12 hours (Agus et al., 2011). Devendra (2011) explains that the ruminant livestock agribusiness system with plants provides socio-economic benefits for small farmers who have low resources, for that an integrated agribusiness system must be applied.

Integrating livestock rearing with other farming activities will provide a fairly high cost efficiency, so as to increase farmers' income. As it is known that the biggest operational cost of the livestock business is the cost of feed, which covers 60-70 percent of the total operational costs. 
The integration system aims to reduce feed costs, thus utilizing crop waste and agroindustry by-products, such as straw (rice and corn), seeds (peanuts can be used as a source of feed and livestock waste in the form of manure is very beneficial for plants, namely to improve soil structure, reduce water absorption, prevent crusting of the soil surface.

The current condition is that livestock and plant businesses are still cultivated in a diversified manner and have not been implemented in an integrated farming manner. For this reason, a Beef Cattle and Crop Integration System (SISPOTTA) model is needed, which is a farming system that integrates beef cattle business with food crops and related components in an integrated manner (integrated crop-livestock system) which can be taken into consideration in program formulation to be implemented at the level of cattle breeders in the region in effort to develop sustainable livestock. Some of the problems that exist in the research area, namely the integration model has begun to be applied, but are still constrained by the factors that affect the performance of each component of production, both beef cattle, plants, waste, biogas, organic fertilizers, as well as the integration of each component in the integration of cattle with food crops.

Optimization of beef cattle business with plants is carried out using the linear programming method to maximize the income that will be obtained by farmers and ranchers in Gorontalo Regency. Gorontalo in the Cattle-Rice-Corn (SPJ), Cattle-Rice-Bean (SPK) and Cattle-Corn-Bean (SJK) businesses. The objective function (optimization) and the constraint function are described below, so linear programming optimization in this research can solve the problem by using software analysis Linear Program Solver (LiPS) and Microsoft Excel.

Finding the Value of Cattle, Rice, and Corn, as well as the optimal value of income:

$$
Z=C_{1} X_{1}+C_{2} X_{2}+C_{3} X_{3}
$$

Where:

C_ $1=$ The value of income raising cattle per year;

$\mathrm{X}_{-} 1$ = Cow Variable;

C_2 = Value of income maintaining rice per year;

$\mathrm{X}$ 2 $=$ Rice Variable;

C_3 = Value of income raising Corn per year;

X_3 = Corn Variable.

It is known that:

$$
\begin{gathered}
C_{1}=8.981 .923,08 \\
C_{2}=7.460 .000 \\
C_{3}=19.910 .000 \\
\\
L=1,13 X_{2}+1,13 X_{3} \leq 2.40 \\
T=36 X_{1}+45 X_{2}+45 X_{3} \leq 120,64 \\
M=18.085 .384,61 X_{1}+11.440 .000 X_{2}+11.440 .000 X_{3} \leq 34.375 .310,91 \\
H=20.000 X_{1} \leq 48015.84 \\
X_{1} \geq 0, X_{2} \geq 0, X_{3} \geq 0
\end{gathered}
$$

Where:

$X_{1}=$ optimized number of cattle (ST);

$X_{2}=$ optimized rice area (ha);

$X_{3}=$ optimized corn acreage (ha).

The results of the first optimization of the cow-rice-corn business with the objective function and constraints that have been set.

Based on the results of the first optimization of cattle, rice, and corn businesses, it was obtained IDR 42,286,700, there has been an increase in income of IDR 516,797 or $1.22 \%$ of the income earned before being analyzed was IDR 41,769,903.46. This shows that farmers' income has not been maximized so that a second analysis is needed to change the formulation and utilize existing resources so that farmers' incomes are maximized. The optimization of the two cattle, rice, and corn businesses is presented in Table 1. 
Table 1 - The results of the optimization of the cattle-rice-corn business with the objective and constraint functions that have been set

\begin{tabular}{llll}
\hline Function & Symbol & Solution & \\
\hline \multirow{3}{*}{ Decision } & Cow & 0.56 & $\mathrm{ST}$ \\
& Rice & 0.00 & $\mathrm{Ha}$ \\
& Corn & 2.12 & $\mathrm{Ha}$ \\
\hline \multirow{3}{*}{ Purpose } & Net weight & $47.291 .800,00$ & $\mathrm{Rupiah}$ \\
& Livestock waste & 4.83 & $\mathrm{Kg} / \mathrm{Day}$ \\
& Rice farming waste & 0.00 & $\mathrm{Kg} / \mathrm{Year}$ \\
& Corn farming waste & $23.754,08$ & $\mathrm{Kg} / \mathrm{Year}$ \\
\hline \multirow{4}{*}{ Problem } & Land & 2.40 & $\mathrm{Ha}$ \\
& Capital & $34.375 .310,91$ & Rupiah \\
& Labor & 120.64 & $\mathrm{HOK}$ \\
& Forage & $48.015,84$ & Rupiah \\
\hline
\end{tabular}

Source: Processed Research Data, 2018.

Table 1 show that in the second analysis it is recommended to raise 0.56 ST cattle and plant 2.12 ha of corn, resulting in the following objectives:

- Net income, reaching to IDR. 47,291,800 per year;

- Utilization of livestock manure for fertilizer as much as $4.83 \mathrm{~kg}$ per day;

- Utilization of agricultural waste as animal feed as much as $23,754.08 \mathrm{~kg} /$ year.

The results of the second optimization analysis are considered to have obtained maximum income; the net income obtained is IDR. 47,291,800, this was an increase of IDR $5,521,897$ or $13.05 \%$. This shows that the first and second analyzes use the same capital, land and labor constraints, but the difference is that the first optimization recommends planting 2.12 ha of corn, not raising cattle and not growing rice, the second optimization recommending raising cattle $0.56 \mathrm{ST}$ and planted rice in an area of $2.12 \mathrm{ha}$, but did not grow rice.

The results of the analysis show that the first optimization of the Cattle, Rice, Peanut business recommends planting peanuts as much as 1.97 ha, without raising cattle and planting rice so as to achieve the following objectives:

- Net income is reaching to IDR. 30,609,800 per year;

- Utilization of livestock waste for fertilizer as much as $0 \mathrm{~kg}$ per day;

- Utilization of agricultural waste as animal feed is $9,617.49 \mathrm{~kg}$ per year.

Based on the results of the first optimization of cattle, rice, and peanut business, it was obtained IDR. 30,609,800, there has been a decrease in income of IDR. 2,553,276.92 or $7.69 \%$. From the results of the income obtained before being analyzed, it was IDR. $33,163,076.92$, the results of the analysis of the cattle, rice, and peanut business are considered not optimal, so that a re-analysis is carried out in order to produce optimization that meets maximum income. The results of the optimization of the two beef-rice-bean businesses with the objective and constraint functions that have been set.

Table 2 - The results of the optimization of the cattle-rice-maize business with the objective and constraint functions that have been set

\begin{tabular}{llll}
\hline Function & Symbol & Solution & \\
\hline \multirow{3}{*}{ Decision } & Cow & 0.67 & $\mathrm{ST}$ \\
& Rice & 0.00 & $\mathrm{Ha}$ \\
& Corn & 1.97 & $\mathrm{Ha}$ \\
\hline \multirow{3}{*}{ Purpose } & Net weight & $36.847 .900,00$ & $\mathrm{Rupiah}$ \\
& Livestock waste & 5.81 & $\mathrm{Kg} / \mathrm{Day}$ \\
& Rice farming waste & 0.00 & $\mathrm{Kg} / \mathrm{Season}$ \\
& Corn farming waste & $9.617,49$ & $\mathrm{Kg} / \mathrm{Season}$ \\
\hline \multirow{4}{*}{ Problem } & Land & 2.40 & $\mathrm{Ha}$ \\
& Capital & $34.375 .310,91$ & $\mathrm{Rupiah}$ \\
& Labor & 120.64 & $\mathrm{HOK}$ \\
& Forage & $48.015,84$ & Rupiah \\
\hline
\end{tabular}

Source: Processed Research Data, 2018. 
Table 2 shows that the second analysis recommends to raise the cattle of 0.67 ST and planting rice in an area of $1.97 \mathrm{ha}$, so that it will produce the following objectives:

- Net income, reaching IDR 36,847,900 per year;

- Utilization of livestock manure for fertilizer as much as $5.81 \mathrm{~kg}$ per day;

- Utilization of agricultural waste as animal feed is $9,617.49 \mathrm{~kg}$ per year.

The results of the second optimization analysis are considered to have obtained maximum income, the net income obtained is IDR 36,847,900, this is an increase of Rp $3,684,823$ or $11.11 \%$. This shows that the first and second analyzes use the same capital, land and labor constraints, but the difference is that the first optimization recommends planting 1.97 ha of beans, not raising cattle and not growing rice, the second optimization recommending raising cattle 0.67 ST and planted rice in an area of 2.12 ha, but did not grow rice.

$$
Z=C_{1} X_{1}+C_{2} X_{2}+C_{3} X_{3}
$$

Where:

$C_{1}=$ The value of income raising cattle per year;

$X_{1}=$ Cow Variable;

$C_{2}=$ Income value of maintaining Corn per year;

$X_{2}=$ Corn Variable;

$C_{3}=$ Income value of keeping Peanuts per year;

$X_{3}=$ Bean Variable.

It is known that:

$$
\begin{gathered}
C_{1}=12.191 .290,32 \\
C_{2}=20.078 .175,18 \\
C_{3}=9.500 .437,96 \\
L=1,56 X_{2}+1,56 X_{3} \leq 2.40 \\
T=36 X_{1}+45 X_{2}+45 X_{3} \leq 120,64 \\
M=13.490 .322,58 X_{1}+11.271 .824,82 X_{2}+11.271 .824,82 X_{3} \leq 34.375 .310,91 \\
H=20.000 X_{1} \leq 48015.84 \\
X_{1} \geq 0, X_{2} \geq 0, X_{3} \geq 0
\end{gathered}
$$

Where:

$X_{1}=$ optimized number of cattle (ST);

$X_{2}=$ optimized corn area (ha);

$X_{3}=$ optimized peanut ara (ha).

It can be seen that the first optimization of the Cattle, Corn, Peanut business recommends planting corn as much as $1.54 \mathrm{ha}$, without raising cattle and planting peanuts so as to achieve the following objectives:

- Net income, reaching IDR 30,889,500 per year;

- Utilization of livestock manure for fertilizer as much as $0 \mathrm{~kg}$ per day;

- Utilization of agricultural waste as animal feed is $23951.05 \mathrm{~kg}$ per year.

Based on the results of the first optimization of cattle, corn, and peanut businesses, it was obtained IDR 30,889,500, there has been an increase in income of IDR 10,880,403.46 or $26.04 \%$. From the results of the income obtained before being analyzed, it was IDR $41,769,903.46$, the results of the analysis of the business of cattle, corn, beans are considered not optimal, so that a re-analysis is carried out to produce optimization that meets maximum income. The optimization of the two cattle, corn and peanut businesses is presented in Table 3. It can be seen that in the second analysis is recommending to raise 1.26 ST cattle and plant 1.54 ha of rice, so that it will produce the following objectives:

- Net income, reaching to IDR 46,283,300 per year;

- Utilization of livestock manure for fertilizer as much as 10.68 kg per day;

- Utilization of agricultural waste as animal feed as much as $23951.05 \mathrm{~kg}$ per year. 
The results of the second optimization analysis are considered to have obtained maximum income, the net income obtained is IDR 46,283,300, and this is an increase of Rp $4,513,396.54$ or $9.75 \%$.

Table 3 - The results of the optimization of the two beef-corn-bean businesses with the established objective and constraint functions

\begin{tabular}{llll}
\hline Function & Symbol & Solution & \\
\hline \multirow{3}{*}{ Decision } & Cow & 1.26 & $\mathrm{ST}$ \\
& Rice & 1.54 & $\mathrm{Ha}$ \\
& Corn & 0.00 & $\mathrm{Ha}$ \\
\hline \multirow{3}{*}{ Purpose } & Net weight & 46283300.00 & $\mathrm{Rupiah}$ \\
& Livestock waste & 10.68 & $\mathrm{Kg} /$ day \\
& Rice farming waste & Kg/Season & Kg/Season \\
\hline \multirow{3}{*}{ Problem } & Corn farming waste & 23951.05 & Ha \\
& Land & 0.00 & Rupiah \\
& Capital & 2.40 & HOK \\
& Labor & 34375310.91 & Rupiah \\
\hline
\end{tabular}

Source: Processed Research Data, 2018.

This shows that the first and second analyzes use the same capital, land and labor constraints, but the difference is that the first optimization recommends planting 1.54 ha of peanuts, not raising cattle and not growing rice, the second optimization recommending keeping cattle 1.26 ST and planted corn in an area of 1.54 ha, but did not plant beans.

The income obtained from the results of the optimization of beef cattle business with plants in Gorontalo Regency can be seen in Table 37 the contribution of income to beef cattle business with plants after the analysis and before the analysis. This data shows that there is an increase in the optimal income goal for cattle, rice, and corn in Gorontalo Regency, namely the second optimization of $30.09 \%$.

Table 4 - Contribution of beef cattle business income with plants after and before analysis

\begin{tabular}{llllll}
\hline No & Business & Optimization & Income after analyzed (IDR) & Income before analyzed (IDR) & Contribution (\%) \\
\hline 1 & S - P -J & First & $42,286,700.00$ & $36,351,923.08$ & 16.33 \\
& & Second & $47,291,800.00$ & $36,351,923.08$ & 30.09 \\
2 & S - P - K & First & $30,609,800.00$ & $33,163,076.92$ & -7.70 \\
& & Second & $36,847,900.00$ & $33,163,076.92$ & 1.11 \\
3 & S-J - K & First & $30,889,500.00$ & $41,769,903.46$ & -26.05 \\
& & Second & $46,283,300.00$ & $41,769,903.46$ & 10.81 \\
\hline
\end{tabular}

Source: Processed Research Data, 2018.

The assumption of a deterministic nature in linear program analysis causes the developed model to be formed in a certainty situation, while in reality a situation that is absolutely certain is rare. For this reason, sensitivity analysis or post optimal analysis is needed to capture uncertainty due to error factors or changes to model parameters. This change is divided into changes in the objective function coefficient (objective function sensitivity) and changes in resource availability constraints (right hand side function sensitivity).

Price changes will not change the integration model, as long as the price changes are still within the sensitivity interval. The sensitivity interval of changes in the coefficient of the objective function in this case is the price change in the rice-livestock model. Even for rice, this rice-livestock integration can still be carried out, but the selling price range for straw and compost is quite narrow, so that farmers do not have a big enough opportunity to develop their business.

\section{CONCLUSION}

Economic value Plant-livestock integration gives the result that the role of ruminants in the agricultural system can reduce farming costs, especially in terms of fertilization. 
Processing of agricultural waste and agro-industrial waste can become new jobs that can absorb labor, benefit livestock and make it easier for farmers to provide feed. Waste treatment also has a double benefit; both are increasing farmers' income while preventing pollution and environmental damage.

\section{REFERENCES}

1. Badan Pusat Statistik Provinsi Gorontalo dan Direktorat Jenderal Peternakan dan Keswan, 2011, Pendataan Sapi Potong, Sapi Perah dan Kerbau Kabupaten Gorontalo.

2. Badan Pusat Statistik Kabupaten Gorontalo dalam angka. 2015. Statistik Daerah Kabupaten Gorontalo 2015, Gorontalo.

3. Bangun, S I, 2005. Analisis Sistim Pertanian Terpadu TanamanTernak Sebagai Model Pertanian Berkelanjutan di Kabupaten Karo (Studi kasus di kecamatan Simpang Empat) Tesis, Sekolah Pascasarjana Universitas Sumatera Utara, Medan.

4. Ditjen Peternakan dan Fapet UGM. 2008. Laporan Survey Inventarisasi Limbah Pertanian. Direktorat Jenderal Peternakan-Fak.Peternakan UGM, Jakarta.

5. Ditjen Peternakan dan Kesehatan Hewan, 2013. Statistik Peternakan dan Kesehatan Hewan 2013, Jakarta.

6. Dinas Peternakan dan Kesehatan Hewan. 2015. Laporan Tahunan Dinas Peternakan dan Kesehatan Hewan Kabupaten Gorontalo

7. Soekartawi, 1995.Linear Program: Teori dan Aplikasinya khusus dalam bidang Pertanian, Rajawali Press, Jakarta, Cetakan ke Dua.

8. Subagyono, D. 2004. Propsek Pengembangan Ternak Pola Integrasi Di Kawasan Perkebunan. Prosiding Seminar Nasional Sistem Integrasi Tanaman-Ternak. Pusat Penelitian dan Pengembangan Peternakan, Badan Litbang Pertanian, Bogor. 